\title{
Serological evidence of tick-borne encephalitis virus infection in moose and deer in Finland: sentinels for virus circulation
}

\author{
Elina Tonteri ${ }^{* *}$, Pikka Jokelainen ${ }^{2,3,4}$, Juho Matala ${ }^{5}$, Jyrki Pusenius ${ }^{5}$ and Olli Vapalahti ${ }^{1,2,6}$
}

\begin{abstract}
Background: The incidence of tick-borne encephalitis (TBE) in humans has increased in Finland, and the disease has emerged in new foci. These foci have been investigated to determine the circulating virus subtype, the tick host species and the ecological parameters, but countrywide epidemiological information on the distribution of TBEV has been limited.

Methods: In this study, we screened sera from hunter-harvested wild cervids for the presence of antibodies against tick-borne encephalitis virus (TBEV) with a hemagglutination inhibition test. The positive results were confirmed by a neutralisation assay.

Results: Nine $(0.74 \%)$ of 1213 moose, one $(0.74 \%)$ of 135 white-tailed deer, and none of the 17 roe deer were found seropositive for TBEV. A close geographical congruence between seropositive cervids and recently reported human TBE cases was observed: nine of the ten seropositive animals were from known endemic areas.

Conclusions: Our results confirm the local circulation of TBEV in several known endemic areas. One seropositive moose had been shot in an area where human TBE cases have not been reported, suggesting a possible new focus. Moose appear to be a useful sentinel animal for the presence of TBEV in the taiga region.
\end{abstract}

Keywords: Moose, Roe deer, Serology, Tick-borne encephalitis, White-tailed deer, Zoonosis

\section{Background}

Tick-borne encephalitis virus (TBEV) is a zoonotic arbovirus. In 1991-2010, it caused up to 12,733 annual reported human cases of tick-borne encephalitis (TBE) in Europe [1]. There are three known genetic subtypes of the virus: European, Siberian and Far-Eastern [2]. The subtypes differ in their endemic regions and ecological preferences, and possibly in their pathogenicity [3].

The virus is maintained in an enzootic cycle of ticks, which are vectors and hosts for the virus, and their vertebrate hosts. Non-viremic transmission (NVT) of TBEV between ticks co-feeding on small vertebrates is considered important for the maintenance of the virus [4]. Due

\footnotetext{
* Correspondence: Elina.rintala@helsinki.fi

'Department of Virology, University of Helsinki, Faculty of Medicine, Helsinki, Finland

Full list of author information is available at the end of the article
}

to the complex ecology of TBEV, its geographical distribution is multifocal [5].

Large mammals are secondary hosts for TBEV as they support the tick populations by providing blood meals. The NVT competence of large mammals is controversial and largely unknown: goats are not NVT-competent, whereas the NVT potential of roe deer (Capreolus capreolus), which can be heavily infested by co-feeding larvae and nymphs, has not been studied [6-10]. Nevertheless, roe deer and red deer (Cervus elaphus) appear to be key hosts for ticks and thereby important for TBEV maintenance [8-10]. In Sweden, the increase in TBE incidence has been associated with changes in cervid populations, especially roe deer populations [11].

TBE is usually subclinical in middle-sized and large mammals [12]. However, in Sweden, a moose (Alces alces) calf with severe behavioral abnormalities and 
subsequently diagnosed encephalitis was found to be TBEV-positive [13].

Finland is at the northern boundary of the current distribution area of TBEV [14]. Two subtypes of the virus, European and Siberian, as well as the two main host tick species, Ixodes ricinus and I.persulcatus, have been described [15]. Between 2007 and 2014, a total of 273 human TBE cases were reported in Finland [16, 17]. The cases occurred mainly in known endemic areas, where human TBE cases have been diagnosed for decades, and where TBEV antibodies were detected in cattle already in the 1960s $[16,18]$. The incidence of human TBE has increased, and the disease has emerged in new foci [16]. Bank vole (Myodes glareolus) appears to be the dominant small mammal in the studied TBEV foci in Finland in the boreal taiga region $[14,19]$. Large and middlesized mammalian species supporting the local maintenance of TBEV have not been investigated.

There are three wild cervid species with substantial populations in Finland. Since the1970's, the moose population has comprised 60,000 to 200,000 individuals that are evenly distributed across the country [20,21]. The whitetailed deer (Odocoileus virginianus) population has 40,000 to 50,000 individuals, that inhabit mainly south-western Finland [22]. The roe deer population of 10,000 to 20,000 individuals is distributed sparsely across the country, with the highest numbers in the south-west [23].

In this study, we screened sera of these three wild cervid species for TBEV-specific antibodies to estimate the seroprevalence and to determine the geographical distribution of TBEV in Finland. We discuss the suitability of moose as a sentinel animal for the presence of TBEV and as an indicator for local risk of human TBE infections.

\section{Methods}

\section{Ethics statement}

No animals were killed for the purpose of this study. The animals were sampled post mortem, after they had been legally killed by hunters. The samples were stored, coded, and all data were treated confidentially.

\section{Study design and sampling}

The serum bank was collected during the hunting season of 2008-2009, primarily for a nationwide crosssectional serological study on Toxoplasma gondii [24]. The sample is a convenience sample, and the sampling was not targeted for TBEV foci. Altogether 2917 sampling packages were distributed to the game management districts, which subsequently distributed them to the hunters. Each package included two plastic VACUETTE ${ }^{\bullet}$ Serum Clot Activator blood sample tubes (Greiner Bio-One GmbH, Kremsmünster, Austria) and a questionnaire covering the game management district, and species, sex and age group of the animal sampled.

All the animals included in the study were legally hunted for human consumption. The voluntarily participating hunters collected the samples from the animals and filled out the questionnaire for each animal. The participation rate was $47 \%$. Samples were sent by mail and arrived at the laboratory within 4 days of sampling, between September 15th 2008 and February 2nd 2009. Upon arrival, the samples were coded, and sera were separated by centrifugation, divided into aliquots and stored at $-20{ }^{\circ} \mathrm{C}$ until analyzed. Only the code number of each sample was known by the persons performing the tests.

A total of 1371 cervid samples were included in this study. The samples from 1213 moose originated from all 15 game management districts. The deer samples, from 135 white-tailed deer and 17 roe deer, had been collected only from the south-western districts where these cervids are the most numerous. The species of six samples was unspecified.

\section{Serological methods}

For the serological analysis for the presence of antiTBEV antibodies, we used an in-house hemagglutination inhibition (HI) test [25] using the following two-fold dilutions: 1:10, 1:20, 1:40, 1:80, 1:160, 1:320, 1:640. Titers were determined according to these dilutions, however, in cases where the last dilution showed partial inhibition of hemagglutination, the titer was determined as the value between the last clear dilution and the borderline dilution and is presented in Table 1 by showing both the lower and higher dilutions. Positive results were further confirmed by a rapid focus-forming inhibition test for neutralizing antibodies using Swedish European subtype strain 93-783 [25]. The test was performed in dilutions 1:5 and 1:20. The samples that tested positive in the HI test and positive or borderline in the neutralisation test were defined as seropositive. In addition, the samples were screened with in-house $\mathrm{HI}$ tests for the presence of antibodies against two other flaviviruses that could cause cross-reactive antibody responses: West Nile virus (WNV), which has not been found in Finland, and Lammivirus (LAMV) which has been found in mosquitoes in Finland [26].

\section{Statistical analyses}

Two-by-two tables and test statistics were used for preliminary comparisons [27]. Logistical regression analyses with Stata 11.0 (StataCorp, College Station, Texas, US) were used to evaluate effects of available explanatory variables (game management district, sex, species, age group) on the outcome variable, TBEV-seropositivity. 
Table 1 Basic data and serological results of the wild cervids hunted in 2008-2009 in Finland that tested seropositive in the screening for antibodies against tick-borne encephalitis virus by hemagglutination inhibition test

\begin{tabular}{|c|c|c|c|c|c|c|c|c|c|c|}
\hline \multirow[t]{3}{*}{ Individual } & \multirow[t]{3}{*}{ Species } & \multirow[t]{3}{*}{ Age } & \multirow[t]{3}{*}{ Sex } & \multirow[t]{3}{*}{ Disrtict $^{a}$} & \multirow{3}{*}{$\begin{array}{l}\mathrm{HI} \\
\text { TBEV }\end{array}$} & \multicolumn{3}{|c|}{ Neutralisation } & \multirow{3}{*}{$\begin{array}{l}\text { HI } \\
\text { WNV }\end{array}$} & \multirow{3}{*}{$\begin{array}{l}\text { HI } \\
\text { LAMV }\end{array}$} \\
\hline & & & & & & \multicolumn{3}{|l|}{ TBEV } & & \\
\hline & & & & & & NT 5 & NT 20 & NT result & & \\
\hline 1. & moose & adult & M & 8 & 640 & $20 / 20$ & $20 / 20$ & neg & neg & $20-40$ \\
\hline 2. & moose & adult & M & 1 & $160-320$ & $0 / 20$ & $6 / 20$ & pos & $<10$ & neg \\
\hline 3. & moose & calf & M & 8 & $160-320$ & $9 / 20$ & $17 / 20$ & pos & neg & neg \\
\hline 4. & moose & adult & M & 5 & $80-160$ & $0 / 20$ & $20 / 20$ & pos & neg & neg \\
\hline 5. & moose & nd. & $\mathrm{F}$ & 8 & 80 & $4 / 20$ & $15 / 20$ & pos & neg & neg \\
\hline 6. & moose & adult & M & 1 & 80 & $0 / 20$ & $10 / 20$ & pos & neg & neg \\
\hline 7. & moose & adult & M & 13 & 80 & $20 / 20$ & $20 / 20$ & neg & neg & neg \\
\hline 8. & moose & adult & M & 3 & 80 & $2 / 20$ & $17 / 20$ & pos & neg & neg \\
\hline 9. & moose & calf & M & 14 & $40-80$ & $10 / 20$ & $20 / 20$ & pos/neg & neg & neg \\
\hline 10. & moose & adult & M & 7 & 40 & $0 / 20$ & $13 / 20$ & pos & neg & $20-40$ \\
\hline 11. & moose & calf & $\mathrm{F}$ & 13 & 40 & $20 / 20$ & $20 / 20$ & neg & neg & neg \\
\hline 12. & moose & adult & M & 14 & $<40$ & $20 / 20$ & $20 / 20$ & neg & neg & neg \\
\hline 13. & moose & adult & $\mathrm{F}$ & 10 & $20-40$ & $20 / 20$ & $20 / 20$ & neg & neg & neg \\
\hline 14. & moose & calf & M & 7 & 20 & $20 / 20$ & $20 / 20$ & neg & neg & neg \\
\hline 15. & deer $^{b}$ & adult & M & 1 & 20 & $12 / 20$ & $20 / 20$ & pos/neg & neg & neg \\
\hline 16. & moose & calf & M & 4 & 20 & $20 / 20$ & $20 / 20$ & neg & neg & neg \\
\hline 17. & moose & calf & $\mathrm{F}$ & 3 & 20 & $16 / 20$ & $20 / 20$ & neg & neg & 10 \\
\hline 18. & moose & adult & $\mathrm{F}$ & 12 & 20 & $18 / 20$ & $20 / 20$ & neg & neg & neg \\
\hline 19. & moose & adult & M & 5 & $<20$ & $20 / 20$ & $20 / 20$ & neg & neg & neg \\
\hline 20. & moose & adult & $\mathrm{F}$ & 1 & $10-20$ & $20 / 20$ & $20 / 20$ & neg & neg & neg \\
\hline 21. & moose & adult & M & 8 & $10-20$ & $14 / 20$ & $20 / 20$ & pos/neg & 10 & $10-20$ \\
\hline 22. & moose & adult & M & 1 & $10-20$ & $20 / 20$ & $20 / 20$ & neg & neg & neg \\
\hline 23. & moose & adult & M & 7 & $10-20$ & $17 / 20$ & $20 / 20$ & neg & neg & neg \\
\hline 24. & moose & calf & M & 3 & $10-20$ & $20 / 20$ & $20 / 20$ & neg & neg & neg \\
\hline 25. & moose & adult & $\mathrm{F}$ & 3 & $10-20$ & $20 / 20$ & $20 / 20$ & neg & neg & neg \\
\hline 26. & moose & adult & $M$ & 1 & $10-20$ & $20 / 20$ & $20 / 20$ & neg & neg & neg \\
\hline 27. & moose & adult & $F$ & 8 & $10-20$ & $16 / 20$ & $20 / 20$ & neg & neg & neg \\
\hline
\end{tabular}

${ }^{a}$ Districts presented in Fig. 1. The game administrative districts are described according to The Finnish Wildlife Agency

bWhite-tailed deer

NT 5 neutralisation test, dilution 1:5

NT 20, neutralisation test, dilution 1:20

$H$ I hemagglutination inhibition test

TBEV tick-borne encephalitis virus

WNV West-Nile virus

LAMV Lammi virus

\section{Results}

Altogether 28 samples tested positive for anti-TBEV antibodies with the HI test (Table 1), and titers ranged from 15 to 640. These sera were further subject to confirmatory analysis by the TBEV neutralisation test. Ten samples showed positive $(<10 / 20)$ or borderline result with dilutions 1:5 (NT 5) or 1:20 (NT 20) and were thus defined as seropositive (Table 1). The samples showing TBEV-specific antibodies by the neutralisation test had higher HI-titers than those samples that tested positive only on the HI test. The seropositive animals consisted of five adult male moose, two adult female moose, two young male moose, and one adult male white-tailed deer.

The ten seropositive animals were from six different game management districts, and their geographical distribution appeared to correlate closely with the known human infection sites: nine seropositive animals originated from areas where human cases have been described (Fig. 1). The seroprevalences in moose and 


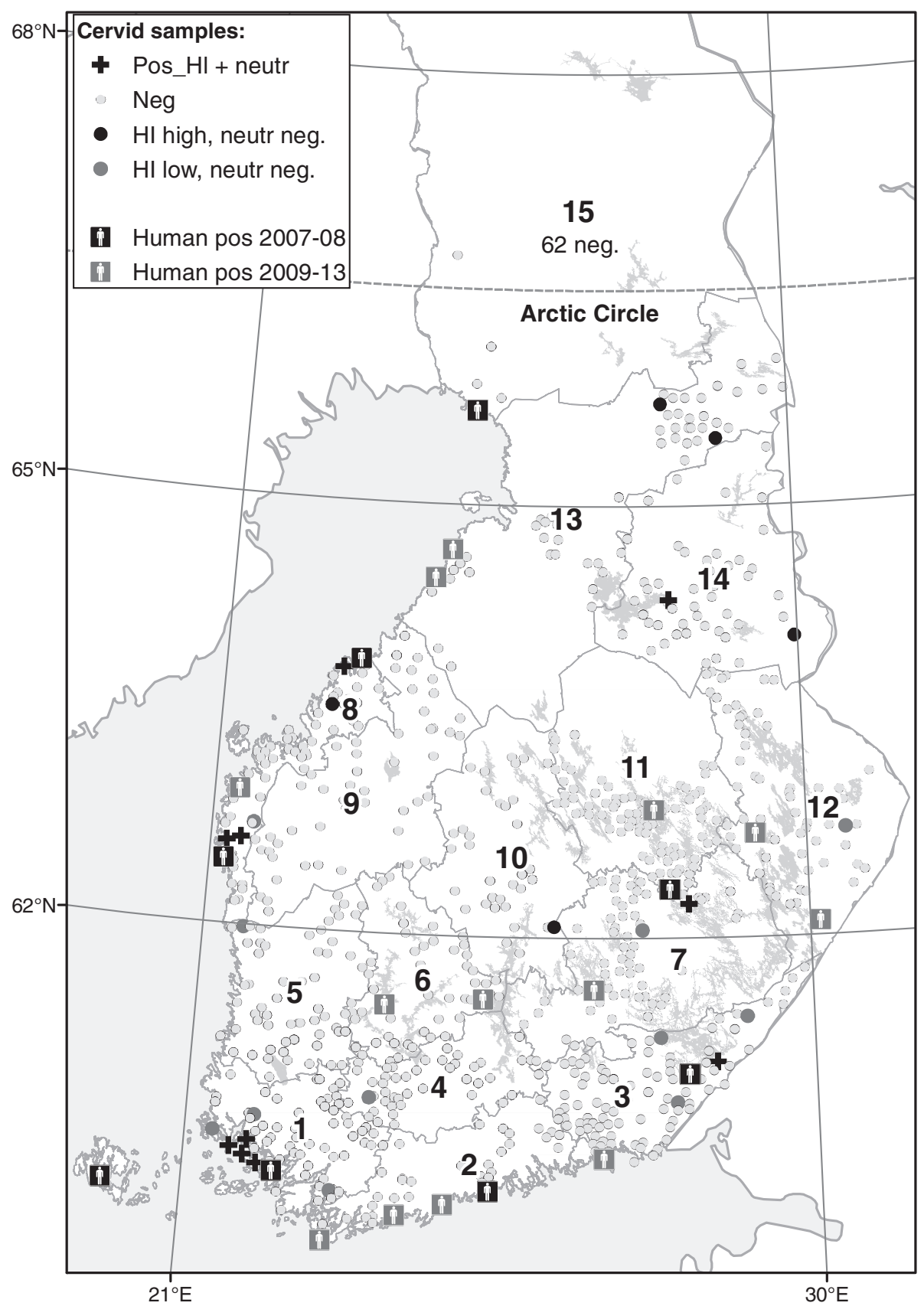

Fig. 1 Geographical distribution of the hunting locations of the tested wild cervids, the animals defined as seropositive for antibodies against tick-borne encephalitis virus, and the cases of human tick-borne encephalitis in Finland. Data on hunting location were available for $79.2 \%$ of the animals. The numbers $1-15$ refer to the game management districts

white-tailed deer were $0.74 \%$, and the seroprevalences did not differ significantly between the species, sexes and age groups (Table 2). Logistic regression analyses revealed no multivariable association.

None of the samples tested positive for WNV. Three of four samples that were weakly positive for LAMV, showed lower titers for this virus than for TBEV in the hemagglutination test (Table 1). One of the LAMV- positive samples showed a rather high hemagglutination titer, but this sample was still also positive for TBEV according to the TBEV neutralisation test (Table 1).

\section{Discussion}

Presence of anti-TBEV-antibodies in moose has been previously investigated apparently only in Sweden in 1962 and more recently in Norway [13, 28]. In the 
Table 2 Prevalence of antibodies against tick-borne encephalitis virus in wild cervids hunted in 2008-2009 in Finland

\begin{tabular}{lllll}
\hline & $\mathrm{n}^{\mathrm{a}}$ & $\mathrm{n}$ positive & Seroprevalence (\%) & 95 \% confidence interval (Mid-P Exact) \\
\hline Moose & & & & $0.46-2.05$ \\
Male & 672 & 7 & 1.04 & $0.07-1.29$ \\
Female & 512 & 2 & 0.39 & $0.42-1.89$ \\
Adult & 729 & 7 & 0.96 & $0.07-1.45$ \\
Calf & 453 & 2 & 0.44 & $0.36-1.36$ \\
All & 1213 & 9 & 0.74 & $0.07-6.24$ \\
White-tailed deer & & & & $0.00-5.12$ \\
Male & 77 & 1 & 1.30 & $0.07-6.75$ \\
Female & 57 & 0 & 0.00 & $0.00-4.57$ \\
Adult & 71 & 1 & 1.41 & $0.04-3.60$ \\
Calf & 64 & 0 & 0.00 & $0.00-23.84$ \\
All & 135 & 1 & 0.74 & $0.00-39.30$ \\
Roe deer & 11 & 0 & 0.00 & $0.00-19.26$ \\
Male & 6 & 0 & 0.00 & $0.00-63.16$ \\
Female & 14 & 0 & 0.00 & $0.00-16.16$ \\
Adult & 3 & 0 & 0.00 & $0.37-1.30$ \\
Calf & 17 & 0.00 & 0.73 & \\
All & 1371 & 0 & & \\
All & 10 & 0 & 0.00 &
\end{tabular}

${ }^{\mathrm{a}}$ Background information was unavailable for some of the animals investigated

Swedish study, the seroprevalence among 75 individuals was $44 \%$, which is almost sixty times higher than the Finnish estimate obtained in this study. The neutralisation test was used in both studies, but the results are not comparable because most of the animals included in the Swedish study had been shot in a known endemic area, whereas this study covered the whole of Finland except for the highly endemic Åland islands. In the Norwegian study, which used a commercial ELISA method, the prevalence was $52 \%$, but the sample size $(N=27)$ was small and the geographical range limited.

In this study, we used an in-house HI test as the primary screening test. Because flaviviruses cause crossreactions in serological analyses, the positive results were confirmed by a labour-intensive, but more specific neutralisation test. To exclude some known cross-reactive flaviviruses, we tested the TBEV-positive samples (in the HI test) also for West Nile virus (WNV) and Lammivirus (LAMV). Low titers of LAMV-specific antibodies were detected in four animals in Southern and Central Finland, while there was no indication of WNV having been introduced in the cervid populations.

Finding serological evidence of TBEV infection in cervids indicates previous TBEV infection. A systemic infection is critical for the development of the specific antibody response. Non-viremic transmission (NVT) in rodents between co-feeding ticks is considered important for the maintenance of the virus and it does not require systemic infection [29, 30]. According to our unpublished observations and the earlier results by Svedmyr et al. [13], moose can be heavily infested by Ixodes ticks. The role of moose as secondary hosts for $\mathrm{TBEV}$ in the taiga region and their potential for NVT during tick co-feeding have not been investigated, but they are likely to have a role in amplifying the tick populations and potentially in introducing infected ticks to new areas.

In Central and Southern Europe as well as in large parts of Sweden, the roe deer is a key host for ticks, and a good indicator for the occurrence of human TBEV infections $[8,10,11,31-34]$. The available estimates of TBEV seroprevalence in roe deer and red deer from other European countries range from 2.4 to $40 \%$, with marked local variation [31, 32, 35-38]. Due to the low number of roe deer samples in our study, the role of roe deer in the spread or circulation of TBEV in Finland could not be evaluated.

In Finland, moose is the most abundant and most widespread wild cervid, while the largest populations and the effective dispersal of roe deer and white-tailed deer are mainly limited to south-west Finland due to harsh winter conditions and thick snow cover in other parts of the country. However, small populations of roe deer exist in Lapland in shore and riverbank areas that 
have less snow $[39,40]$. In Sweden, the geographic expansion of $I$. ricinus has followed the increase and dispersal of roe deer [11]. In Finland, the dispersal of white-tailed deer is not as effective and widespread as that of roe deer [41]. Interestingly, according to unpublished data of Finnish game authorities and the incidence and geographical distribution of human TBE [16], the emergence of new human cases seemed to coincide with the spread and increase of roe deer and white-tailed deer populations at the turn of the millenium in Finland. On the other hand, the same areas have had large moose populations and there are several other species that may also support the tick populations [42-44]. Most of the studies available have focused on single secondary host species. Sampling of all cervid species in known endemic areas might elucidate their roles in the spread and circulation of TBEV.

Collecting samples from cervids in co-operation with hunters proved successful and useful for evaluating the epidemiology of zoonotic diseases ([24] and this study). To analyse the role of moose for the local epidemiology and for the monitoring of TBEV locally and countrywide, repeated hunter-harvested sampling from cervids could be used alongside the continuous monitoring of human TBE. Good sample sizes are achievable, and sampling animals that were killed for another reason is ethically sound.

There were more males than females among the sampled animals, and male cervids dominate also in the annual hunting statistics in Finland [21, 45]. Eight of the ten seropositive animals were male. Male moose and young individuals migrate across a wider range and might therefore have more possibilities to encounter an infected tick and also to carry ticks to new locations [46]. In roe deer, higher TBEV-antibody prevalence has been seen in males even after the mobility is excluded [32]. In this study, the positive results were detected mainly in areas, which are known to be endemic for TBEV.

Among the animals included in this study, $37.9 \%$ were calves (less than 1 year old), which is a smaller proportion than in the game statistics of Finland [21]. All animals included in the study had experienced at least one tick-feeding season, but the exact ages of the adult animals were not determined. Assuming that the antibodies persist, it cannot be estimated when the infections were acquired. Comparing the antibody prevalence in old individuals with the prevalence in young individuals could be used to determine whether the incidence of infections is increasing in the area. In this study, the prevalences were similar, suggesting recent introduction, or increasing infection pressure.

The only previous countrywide serological survey on the distribution and prevalence of TBEV infection in
Finland was done in 1960 s by screening TBEV antibodies in cattle serum samples [18]. The seropositive cattle were from areas where human cases have been diagnosed for decades. In this study, several seropositive wild cervids were shown to inhabit the same areas.

During the two previous tick-feeding seasons before the collecting of the cervid samples, human cases had been reported in eight areas in Finland (Fig. 1). In this study, seropositive cervids were detected in six of the eight areas. Finding no seropositive cervids in two of the eight areas may be explained by sampling bias: for example, the Helsinki focus is an island with no hunting activity. Finding no seropositives around the foci supports the previous observations that distribution of TBEV is highly focal.

One seropositive moose male calf (individual 9, Table 1) was from Kainuu, an area with no reports of human TBE cases. As a calf under 1 year of age follows a cow, and cows with calves usually do not do dispersal migrations, it is most likely that this individual had encountered the virus locally. This result could thus suggest a possible new TBEV focus, which calls for further monitoring of the area for TBEV circulation and potential human cases.

In Finland, the human TBE cases have emerged mainly nearby water - in the archipelago, coastal regions, and near big lakes [16]. This distribution of human TBE cases may be due to the high density of summer cottages by water as well as long exposure times during the summer holidays, which overlap with the tick feeding season. Other explanations for the proximity of human TBE cases to water include the ecological factors that cause the highly focal distribution of TBEV in favourable microclimatic conditions. Summer habitats of cervids are often also nearby water $[47,48]$ and moose are known to use water to cool off [49]. Furthermore, dispersal of roe deer has followed the seashores, rivers, and lakes [40]. These habitat preferences might enhance the potential role of cervids in maintaining tick populations that enable TBEV circulation.

During recent years, human TBE cases have been reported in new areas in Finland, and the strictly focal pattern may be changing towards a coalescing distribution $[14-16,50]$. The results of this study suggest that moose could serve as sentinels and indicators for risk for human TBEV infections in the taiga region where deer, commonly used as sentinels for TBEV risk for humans, are not widespread. Surveying anti-TBEV antibodies in wild cervids could be a useful tool for monitoring this zoonosis.

\section{Conclusions}

Anti TBEV-antibodies were detected in ten free-ranging cervids in Finland. The infections were presumably autochthonous, naturally acquired by the cervids from 
their local natural environment. Nine out of ten seropositive animals had been hunted in areas where human TBE cases have occurred, confirming the local circulation of the virus in the foci. Our study also found one possible new focus, as one seropositive moose male calf was from an area with no reports of human TBE cases. Our observation of the geographical congruence between the human cases and seropositive moose suggest that moose could serve as sentinels and indicators for TBEV risk to humans.

\section{Abbreviations}

HI: hemagglutination inhibition test; LAMV: Lammi virus; NVT: non-viremic transmission; TBE: tick-borne encephalitis; TBEV: tick-borne encephalitis virus; WNV: West Nile virus.

\section{Competing interests}

E. Tonteri has received a lecturing fee from Pfizer Ltd for giving a lecture in the International Scientific Working Group on Tick-Borne Encephalitis (ISW-TBE) meeting, January 2015. The other authors declare that they have no competing interests.

\section{Authors' contributions}

ET, PJ and OV designed the study. PJ was responsible of planning the original sampling. ET did the laboratory work. All authors contributed to the writing process of the manuscript: ET and OV contributed especially to the TBE aspects, ET, PJ and OV to zoonotic and epidemiological aspects, and JM and JP to ecological and game management aspects. All authors accepted the final version of this manuscript to be submitted for publication.

\section{Acknowledgements}

The authors would like to express their gratitude to Irina Suomalainen, University of Helsinki and Sirkka Vene, The Public Health Agency of Sweden, for their help with the serological assays, and to the hunters and the staff of Veterinary Pathology and Parasitology, Department of Veterinary Biosciences, Faculty of Veterinary Medicine, University of Helsinki for the contributions to the original sampling. We thank Vesa Nivala (Natural Resources Institute Finland) for drawing themap. The work was financially supported by the Finnish Foundation of Veterinary Research, Strategic Development Fund of the Estonian University of Life Sciences, Academy of Finland, and the Helsinki University Hospital funds.

\section{Author details}

'Department of Virology, University of Helsinki, Faculty of Medicine, Helsinki, Finland. ${ }^{2}$ Department of Veterinary Biosciences, University of Helsinki, Faculty of Veterinary Medicine, Helsinki, Finland. ${ }^{3}$ Department of Food Hygiene and Environmental Health, University of Helsinki, Faculty of Veterinary Medicine, Helsinki, Finland. ${ }^{4}$ Department of Basic Veterinary Sciences and Population Medicine, Estonian University of Life Sciences, Tartu, Estonia. ${ }^{5}$ Natural Resources Institute Finland (Luke), Management and Production of Renewable Resources, Joensuu, Finland. ${ }^{6}$ Department of Virology and Immunology, Hospital district of Helsinki and Uusimaa (HUSLAB), Helsinki, Finland.

Received: 9 July 2015 Accepted: 21 January 2016

Published online: 29 January 2016

\section{References}

1. Suss J. Tick-borne encephalitis 2010: epidemiology, risk areas, and virus strains in Europe and Asia-an overview. Ticks Tick Borne Dis. 2011;2:2-15.

2. Ecker M, Allison SL, Meixner T, Heinz FX. Sequence analysis and genetic classification of tick-borne encephalitis viruses from Europe and Asia. J Gen Virol. 1999:80:179-85.

3. Gritsun TS. Tick-borne Flaviviruses. Adv in Virus Res. 2003;61:317-71.

4. Labuda M. Survival strategy of tick-borne encephalitis virus: Cellular basis and environmental determinants. Zentralbl Bakteriol. 1999;289(5-7):513-24.
5. Randolph SE, Green RM, Peacey MF, Rogers DJ. Seasonal synchrony: the key to tick-borne encephalitis foci identified by satellite data. Parasitology. 2000;121(Pt1):15-23.

6. Carpi G, Cagnacci F, Neteler M, Rizzoli A. Tick infestation on roe deer in relation to geographic and remotely sensed climatic variables in a tick-borne encephalitis endemic area. Epidemiol Infect. 2008;136(10):1416-24.

7. Labuda M, Elecková E, Licková M, Sabó A. Tick-borne encephalitis virus foci in Slovakia. Int J Med Microbiol. 2002;291(Suppl: 33):43-7.

8. Knap N, Avšič-Županc T. Correlation of TBE incidence with red deer and roe deer abundance in Slovenia. PLOS ONE. 2013;8(6):e66380.

9. Kiffner C, Lödige C, Alings M, Vor T, Rühe F. Attachment site selection of ticks on roe deer, Capreolus capreolus. Exp Appl Acarol. 2011;53(1):79-94

10. Rizzoli A, Hauffe HC, Tagliapietra V, Neteler M, Rosà R. Forest structure and roe deer abundance predict tick-borne encephalitis risk in Italy. PLoS ONE. 2009;4(2):e4336.

11. Jaenson TG, Hjertqvist M, Bergstrom T, Lundkvist $\AA$. Why is tick-borne encephalitis increasing? A review of the key factors causing the increasing incidence of human TBE in Sweden. Parasit Vectors. 2012:5:184.

12. Hubálek Z, Rudolf I, Nowotny N. Arboviruses pathogenic for domestic and wild animals. Adv Virus Res. 2014:89:201-75.

13. Svedmyr A, von Zeipel G, Borg K, Hansen HJ. Infections with tick-borne encephalitis virus in the Swedish population of the elk (Alces $a$. alces). Acta Pathol Microbiol Scand. 1965;65:613-20.

14. Jaaskelainen $A E$, Tonteri $E$, Sironen T, Pakarinen L, Vaheri A, Vapalahti O. European subtype tick-borne encephalitis virus in Ixodes persulcatus ticks. Emerg Infect Dis. 2011;17(2):323-5.

15. Jaaskelainen A, Korhonen $\mathrm{T}$, Kuusi M, Vapalahti O. Tick-borne encephalitis in Finland. EpiNorth. 2011;12:40-3.

16. Tonteri E, Kurkela S, Timonen S, Manni T, Vuorinen T, Kuusi M, et al. Surveillance of endemic foci of tick-borne encephalitis in Finland: Evidence of emergence of new foci. Euro Surveill.2015; 17:20(37). doi: 10.2807/15607917.ES.2015.20.37.30020

17. National Infectious Diseases Register. National Institute for Health and Welfare, Helsinki, Finland. 2015. http://www.thl.fi/fi_Fl/web/infektiotaudit-fi/ tartuntatautirekisteri. Accessed $21^{\text {st }}$ September 2015

18. Tuomi J, Brummer-Korvenkontio M. Antibodies against viruses of the tick-borne encephalitis group in cattle sera in Finland. Ann Med Exp Biol Fenn. 1965;43:149-54.

19. Tonteri $E$, Jääskeläinen $A E$, Tikkakoski $T$, Voutilainen $L$, Niemimaa J, Henttonen $\mathrm{H}$, et al. Tick-borne encephalitis virus in wild rodents in winter, Finland, 2008-2009. Emerg Infect Dis. 2011;17:72-5.

20. Nygrén T. The history of moose in Finland. Swedish Wildlife Research. 1987;1(Suppl1, Part 1):49-54.

21. Lavsund S, Nygrén T, Solberg EJ. Status of moose populations and challenges to moose management in Fennoscandia. Alces. 2003:39:109-30

22. Kekkonen J, Wikström M, Brommer JE. Heterozygosity in an isolated population of a large mammal founded by four individuals is predicted by an individual-based genetic model. PLoS ONE. 2012;7(9):e43482.

23. Riistaweb 2014, Finnish Wildlife Agency \& Finnish Game and Fisheries Research Institute, https://riistaweb.riista.fi/riistatiedot/riistatietohaku. mhtml?lang=en, Accessed 17th October 2014.

24. Jokelainen $P$, Näreaho A, Knaapi S, Oksanen A, Rikula U, Sukura A. Toxoplasma gondii in wild cervids and sheep in Finland: north-south gradient in seroprevalence. Vet Parasitol. 2010;171:331-6.

25. Vene S, Haglund M, Vapalahti O, Lundkvist $\AA$. A rapid fluorescent focus inhibition test for detection of neutralizing antibodies to tick-borne encephalitis virus. J Virol Methods. 1998;73(1):71-5.

26. Putkuri N, Kurkela S, Manni T, Vaheri A, Vapalahti O, Uzcátegui NY Characterization of a novel flavivirus from mosquitoes in northern Europe that is related to mosquito-borne flaviviruses of the tropics. J Virol. 2009;83(18):9532-40

27. Dean AG, Sullivan KM, Soe MM. OpenEpi: Open Source Epidemiological Statistics for Public Health. Available from www.openepi.com. Accessed 2014.

28. Ytrehus B, Vainio K, Dudman SG, Gilray J, Willoughby K. Tick-borne encephalitis virus and louping-ill virus may co-circulate in Southern Norway. Vector Borne Zoonotic Dis. 2013:13(10):762-8.

29. Labuda M, Kozuch O, Zuffova E, Eleckova E, Hails RS, Nuttall PA. Tick-borne encephalitis virus transmission between ticks cofeeding on specific immune natural rodent hosts. Virology. 1997;235(1):138-43. 
30. Randolph SE, Gern L, Nuttall PA. Co-feeding ticks: epidemiological significance for tick-borne pathogen transmission. Parasitol Today. 1996;12:472-9.

31. Balling A, Plessow U, Beer M, Pfeffer M. Prevalence of antibodies against tick-borne encephalitis virus in wild game from Saxony, Germany. Ticks Tick Borne Dis. 2014;5:805-9.

32. Gerth HJ, Grimshandl D, Stage B, Döller G, Kunz C. Roe deer as sentinels for endemicity of tick-borne encephalitis virus. Epidemiol Infect. 1995;115(2):355-65.

33. Kiffner C, Zucchini W, Schomaker P, Vor T, Hagedorn P, Niedrig M, et al. Determinants of tick-borne encephalitis in counties of southern Germany, 2001-2008. Int J Health Geogr. 2010;9:42.

34. Skarphédinsson S, Jensen PM, Kristiansen K. Survey of tickborne infections in Denmark. Emerg Infect Dis. 2005;11(7):1055-61.

35. Duscher GG, Wetscher M, Baumgartner R, Walder G. Roe deer sera used for TBE surveillance in Austria. Ticks Tick Borne Dis. 2015;6(4):489-93.

36. Kiffner C, Vor T, Hagedorn P, Niedrig M, Rühe F. Determinants of tick-borne encephalitis virus antibody presence in roe deer (Capreolus capreolus) sera. Med Vet Entomol. 2012;26:18-25.

37. Linden A, Wirtgen M, Nahayo A, Heyman P, Niedrig M, Schulze Y. Tickborne encephalitis virus antibodies in wild cervids in Belgium. Vet Rec. 2012;170(4):108.

38. Imhoff M, Hagedorn P, Schulze Y, Hellenbrand W, Pfeffer M, Niedrig M. Review: Sentinels of tick-borne encephalitis risk. Ticks Tick Borne Dis. 2015:6(5):592-600.

39. Helle P. Food composition and feeding habits of the roe deer in winter in central Finland. Acta Theriol. 1980;25(22):395-402.

40. Pulliainen E. Occurence and spread of the roe deer (Capreolus capreolus L.) in eastern Fennoscandia since 1970. Memoranda Soc. Fauna Flora Fennica. 1980;56(1):28-32.

41. Honzová M.Analysis of habitat size and migration of roe and white-tailed deer in Finnish lake district, Finland. Diploma Thesis, Faculty of Forestry and Wood Technology, Mendel University in Brno 2013. Available from http://is. mendelu.cz/lide/clovek.pl?id=16527;zalozka=7;studium =50543;zp=42269. $71 p$ Accessed 20th September 2015

42. Jemeršić L, Dežđek D, Brnić D, Prpić J, Janicki Z, Keros T, et al. Detection and genetic characterization of tick-borne encephalitis virus (TBEV) derived from ticks removed from red foxes (Vulpes vulpes) and isolated from spleen samples of red deer (Cervus elaphus) in Croatia. Ticks Tick Borne Dis. 2014;5(1):7-13

43. Palo RT. Tick-borne encephalitis transmission risk: its dependence on host population dynamics and climate effects. Vector Borne Zoonotic Dis. 2014;14(5):346-52.

44. Rizzoli A, Silaghi C, Obiegala A, Rudolf I, Hubálek Z, Földvári G, et al. Ixodes ricinus and its transmitted pathogens in urban and peri-urban areas in Europe: new hazards and relevance for public health. Front Public Health, 2014:2:251.

45. Tiilikainen R, Nygrén T, Pusenius J, Ruusila V. Variation in growth pattern of male moose Alces alces after two contrasted periods of hunting. Ann Zool Fennici. 2010;47:159-72.

46. Singh NJ, Börger L, Dettki H, Bunnefeld N, Ericsson G. From migration to nomadism: movement variability in a northern ungulate across its latitudinal range. Ecol Appl. 2012;22:2007-20.

47. Ceacero F, Landete-Castillejos T, Miranda M, Garcia AJ, Martinez A, Gallego L. Why do cervids feed on aquatic vegetation? Behav Process. 2014;103:28-34

48. Faber W, Person Å, Cederlund G, Jordan PA. Aquatic feeding by moose in Sweden - with implications concerning sodium. Alces. 1998;24:126-32.

49. Melin M, Matala J, Mehtätalo L, Tiilikainen R, Tikkanen O-P, Maltamo M, et al. Moose (Alcesalces) reacts to high summer temperatures by utilizing thermal shelters in boreal forests - an analysis based on airborne laser scanning of the canopy structure at moose locations. Global Change Biol. 2014;20(4):1115-25.

50. Jääskeläinen A, Tonteri E, Pieninkeroinen I, Sironen T, Voutilainen L, Kuusi M, et al. Siberian subtype tick-borne encephalitis virus in Ixodes ricinus in a newly emerged focus, Finland. Ticks Tick Borne Dis. 2016;7(1):216-23.

\section{Submit your next manuscript to BioMed Central and we will help you at every step:}

- We accept pre-submission inquiries

- Our selector tool helps you to find the most relevant journal

- We provide round the clock customer support

- Convenient online submission

- Thorough peer review

- Inclusion in PubMed and all major indexing services

- Maximum visibility for your research

Submit your manuscript at www.biomedcentral.com/submit
C Biomed Central 